\title{
Critical timing for reproductive allocation in a capital breeder: evidence from sandeels
}

\author{
Philip Boulcott ${ }^{1,2, *}$, Peter J. Wright ${ }^{1}$ \\ ${ }^{1}$ Fisheries Research Services Marine Laboratory, PO Box 101, Victoria Road, Aberdeen AB11 9DB, UK \\ ${ }^{2}$ Present address: Division of Animal Production and Public Health, Faculty of Veterinary Medicine, University of Glasgow, \\ 464 Bearsden Road, Glasgow G61 1QH, UK
}

\begin{abstract}
Life-history theory predicts a tradeoff in resource allocation between early maturation and growth in species which exhibit indeterminate growth. However, since life-history models assume that the fitness payoff of each developmental strategy at completion is known, they are unable to encapsulate the mechanics by which maturation is controlled under natural conditions. To determine the proximate conditions which influence variation in reproductive investment, we recorded somatic growth, sexual maturation and fecundity in individually marked first-time maturing lesser sandeels Ammodytes marinus. Cytological investigation revealed that the transition in gonad development from primary to secondary stages occurred between June and August in both sexes. Using logistical regression, variation in maturation could be attributed to both initial weight and observed differences in resource accrual during this period, suggesting that if growth prior to this period is inadequate in smaller fish then maturation remains inhibited. For those females that did mature, potential fecundity positively correlated with final body size. Our findings indicate that small changes in the timing of the availability of their zooplankton prey could explain the large regional variability in maturity at age exhibited by sandeels in the field.
\end{abstract}

KEY WORDS: Sandeels $\cdot$ Energy allocation $\cdot$ Critical period $\cdot$ Growth $\cdot$ Fecundity $\cdot$ Vitellogenesis Resale or republication not permitted without written consent of the publisher

\section{INTRODUCTION}

When growth is indeterminate, mature individuals experience a tradeoff in resource allocation between reproduction and growth throughout life (Roff 1992). Ultimately, an animal's maturation strategy is expected to depend on the relative fitness benefits of either reproducing at present at a cost to future fecundity or survival, or of reproducing at a larger size in the future at a cost to present fecundity and mortality between reproductive ages (Fisher 1930, Stearns 1992). Which strategy is optimal may depend on several factors including: size-dependent fecundity, size-dependent mortality and the mortality risk associated with reproduction (for a review of life-history theory see Roff 2002).

Whilst life-history theory applied at the species level can explain the selective forces that maintain variation in age or size at maturity, its relevance is diminished when considering the developmental paths which individuals use to resolve life-history decisions. This is because life-history models are essentially post hoc models (Thorpe et al. 1998), attributing known fitness payoffs to each strategy at the time of execution, and are unable to encapsulate the mechanics of a decision process employed under conditions of uncertainty. Therefore, to understand the mechanism underlying the decision to mature we must examine the proximate influences on reproductive investment which reflect the opportunities available for growth and the risk of mortality (Roff 1991). The concept of a nutritionally sensitive 'critical period' provides a plausible explanation for how individuals can assess these constraints when deciding to reproduce for the first time (Thorpe et al. 1998) and is supported by recent evidence of active inhibition of maturation revealed from brain 
gene expression (Aubin-Horth et al. 2005). This hypothesis proposes that as an animal develops through the juvenile stage it enters a period of liability, wherein maturation may be induced depending on energetic status (Burton 1994, Henderson \& Wong 1998) and/or the rate of acquisition of surplus energy (Thorpe et al. 1990, Rijnsdorp 1993, Thorpe et al. 1998). The period of liability usually relates to the time of year when animals must decide whether to commit to the most energetically demanding phase of gonad development, i.e. vitellogenesis in females (Burton 1994, Tyler \& Sumpter 1996) or spermatocyte production in males (Rowe \& Thorpe 1990). Although the physiological changes which take place in the pituitary-gonad axis during maturation are still poorly understood in fish, recent evidence suggests that insulin-like Growth Factor 1 performs an important role in linking body growth to such oocyte development (Campbell et al. 2003, 2006).

Critical periods are pronounced in the many boreal and temperate species that build up energy reserves during a short growing season and spawn outside this season (Roff 1992). The lesser sandeel Ammodytes marinus (Raitt 1934) is one such example, spawning as it does several months after the summer growing season (Winslade 1971, Gauld \& Hutcheon 1990). Sandeels are short-lived, spending a considerable part of the year buried in sand (Macer 1966). Observations on the availability of A. marinus to fisheries (Macer 1966) and their occurrence in sediment (Wright et al. 2000) suggests that sandeels in the North Sea rarely emerge from the seabed between September and March, except to spawn in December and January (Macer 1966, Gauld \& Hutcheon 1990). This annual cycle of burying means that the energy for reproduction has to be stored during the active foraging phase (April to August) and then transferred at some stage prior to the spawning period; hence, they are capital breeders. Because they cannot feed whilst buried, energy allocation to reproduction during the overwinter phase means that energy is diverted away from somatic maintenance and growth.

Data collected from wild, North Sea sandeel stocks has revealed considerable variation in size and age at first maturity (Boulcott et al. 2006), yet, which proximate conditions influence variation in reproductive investment in this species is unknown. Whilst there is no published information on long-term variability in sandeel maturity, a recent analysis of sandeel growth off the southeast Scottish coast detected a significant decline in size at maturity during the last $30 \mathrm{yr}$ (Wanless et al. 2004). That variability in age at maturity is influenced by a combination of genetic and environmental factors (Thorpe et al. 1983, Gjedrem 1986, Aubin-Horth et al. 2005) means that maturation data collected from wild stocks are of only limited value in the elucidation of proximal influences affecting maturation (Rowe \& Thorpe 1990). Hence, to understand how different life-history strategies arise, we need to study the development of known individuals.

The aim of this paper is to examine the timing and cause of maturation decision in Ammodytes marinus. First, by examining gonad development in sequential samples throughout the present study, we investigated the timing of vitellogenesis or spermatocyte production in this species, identifying key energetic stages in the maturation process. Next, using individual growth profiles of potential first-time spawners collected from a single population, we were able to quantify individual variability in growth, comparing this variation with the maturity decisions taken later in the year. Finally, we examined energetic investment in reproduction for first-time spawners and assessed the variability of reproductive investment in terms of fecundity at size.

\section{MATERIALS AND METHODS}

Subjects. Age-1 Ammodytes marinus juveniles were caught using a pelagic trawl (Methot Isaacs Kidd Trawl) off the east coast of Scotland $\left(56^{\circ} 58^{\prime} \mathrm{N}, 02^{\circ} 09^{\prime} \mathrm{W}\right)$ during 2 catches in 2004 ( 2 April and 7 May), soon after their emergence from the sand and at a time close to the onset of their second seasonal growth period. Information from commercial catch data has revealed that most sandeels would be expected to commit to maturity during their second growth period (Macer 1966, Boulcott et al. 2006). Hence, in order to maximise the number of age-1, first-time spawners reared in the present study, only those fish that were found to be within the 8.5 to $14 \mathrm{~cm}$ total length range were selected (see Wanless et al. 2004). That subjects were collected from 2 catches was due to the relative scarcity of sandeels in the sampled area during 2004.

The rearing environment. The present study was conducted at the FRS Marine Laboratory, Aberdeen, between June and December, 2004. Upon arrival at the laboratory, fish were housed in two $450 \mathrm{l}$ rearing tanks according to their date of capture and were given at least $1 \mathrm{mo}$ to acclimate to laboratory conditions before the onset of monitoring (17 June 2004). A total of 280 fish were tested with 140 individuals from each sample housed in the 2 tanks. Prior to their transferal each fish was individually marked with visible implant tags (Northwest Marine Technology) inserted subepithelially into the dorsal region of the flank, in line with the tip of the pectoral fin.

Fish were provided with Artemia spp. and frozen zooplankton to excess during daylight hours. Uneaten food was removed from the tank after $24 \mathrm{~h}$. After being rinsed with seawater to reduce the amount of silt, sand 
with particles not greater than $2 \mathrm{~mm}$ in diameter was used to provide a suitable substrate (see Wright et al. 2000). Tanks were supplied with flow-through water, pumped from a local bay, and were subject to the ambient photoperiod cycle. Temperatures in each tank were recorded every 20 min using a data logger (Minilog-12bit, VEMCO) and were found to be identical, increasing from $11.1^{\circ} \mathrm{C}$ in July to a high of $11.5^{\circ} \mathrm{C}$ in August (see Fig. 2c) and gradually decreasing thereafter. Such a pattern is characteristic of Scottish east coast waters (G. Slesser \& W. Turrell, unpubl. data). Day-length conditions were identical in both tanks. That temperature and light levels were equal in each tank was necessary as both longer day length and higher temperature have been found to affect activity in the sandeel in particular (Winslade 1974a,b) and the timing and prevalence of maturation of fish species in general (Scott \& Sumpter 1983, Norberg et al. 2001).

Data collection and sampling. To obtain an accurate profile of growth, the present study was punctuated by 6 sampling bouts: 17 June, 28 June, 22 July, 17 August, 14 September and 04 October, 2004. Prior to each sample, fish were food-deprived for $2 \mathrm{~d}$ in order to ensure that their stomachs were empty. Under anaesthesia (MS-222, $\left.75 \mathrm{mg} \mathrm{l}^{-1}\right)$, weight $( \pm 0.1 \mathrm{~g})$ and total length $( \pm 0.1 \mathrm{~cm})$, taken from the tip of the mandible to the ventral lobe of the caudal fin, were recorded. Growth rates were calculated according to Svåsand et al. (1996), where: daily specific growth rate $(\mathrm{G})=100 \times[\ln (M$ on day $b)-\ln (M$ on day $a)] /(b-a)$, where $M$ is the body weight $(\mathrm{g})$; and daily length increment $(\mathrm{I})=100 \times[$ total length on day $b$ - total length on day $a] /(b-a)$.

All fish were killed during a further sampling bout in November, a period prior to the start of spawning (Gauld \& Hutcheon 1990). Relative condition factor $\left(K_{n}\right)$ was calculated after Le Cren (1951):

$$
K_{n}=100 \times\left(\frac{W}{\hat{W}}\right)
$$

where $W$ is the individual wet weight $(g)$, and $\hat{W}$ is the predicted weight for a given length $(L)$ based on a weight-length relationship ( $W=a L^{b}$ ) calculated for all subjects. Liver and gonad weights $( \pm 0.001 \mathrm{~g})$ were also recorded. Due to a lack of prominent external features with which to aid classification, sex and maturity status could only be recorded once fish had been killed. Once killed, the assessment of maturity was made macroscopically. Sexual maturation was characterised in males by the enlargement and convolution of the testes, which at this stage became white in colour. In females, mature ovaries were defined as those with oocytes in the early to late stages of vitellogenesis. No fish examined showed evidence of having spawned, i.e. no post-ovulatory follicles or hydrated oocytes were detected during cytological examination. Age was esti- mated from counts of annual increments by immersing the sagittal otoliths in $80 \%$ ethanol and viewing them under reflected light against a black background at $60 \times$ magnification. Classification followed the protocol laid down in ICES CM (1995) and was carried out by an experienced age reader. All fish were killed according to UK Home Office guidelines.

Cytological study. A total of 52 samples (25 male and 27 female) were obtained for cytological study. Samples were collected every $28 \mathrm{~d}$ from the initial June start date by randomly selecting 5 fish from each tank. The gonads of these sampled fish were fixed in $8 \%$ phosphate-buffered formalin, dehydrated and then embedded in a methacrylate polymer resin (Teknovit, TAAB Laboratories Equipment). Sections $3 \mu \mathrm{m}$ thick were cut using a motorised microtome and stained with a $0.5 \%$ solution of toluidine blue. Ovaries were staged, based on the status of the most advanced oocytes, using the following criteria:

Early Primary (perinucleolar stage)

Late Primary (circumnuclear ring stage)

Endogenous vitellogenesis (cortical aveoli)

Exogenous vitellogenesis (yolk granules)

Testicular development was based on the classification used by Dziewulska \& Domagala (2003) where the appearance of cystic structures containing type B spermatogonia in the lobules is indicative of an initial maturation decision and the production of spermatozoa taken to reflect the period of high testicular investment.

Estimating potential fecundity. Potential fecundity, defined as the number of vitellogenic oocytes in the ovary just prior to spawning (Kjesbu et al. 1998), was estimated in all mature females using the autodiametric fecundity method (Thorsen \& Kjesbu 2001). Ovaries for the present study were collected from mature females during the final sampling bout in late November. Since no published parameters for this method exist for Ammodytes marinus, the necessary parameters were obtained from an examination of 300 sandeels collected in a separate study. Egg numbers in this preliminary study were estimated using the gravimetric method (Bagenal 1978). A comparison of oocyte size distribution in the ovary during vitellogenesis, comparing mean ovary diameter in the lobe of the ovary with central sections, revealed oocyte size distribution to be homogeneous in this species (2-tailed $t$-test: $t=0.322$, df $=17, \mathrm{p}=0.75$ ). Such a condition has been found in other sandeel studies (Bergstad et al. 2001) and is necessary for the successful application of the auto-diametric method.

Under the auto-diametric method, predicted potential fecundity $\left(F_{\mathrm{PP}}\right)$ was expressed by the following regression: 


$$
F_{\mathrm{PP}}=M_{\mathrm{O}} \times 2605.6 D_{\mathrm{O}}^{-2.7689} ; 250<D_{\mathrm{O}}<1000
$$

where $M_{\mathrm{O}}$ is the ovarian weight $(\mathrm{g})$ and $D_{\mathrm{O}}$ is the mean oocyte diameter in a fresh ovary $(\mu \mathrm{m})$. In each instance, mean oocyte diameter was estimated from a sample of 100 to 200 oocytes. To mitigate the inflationary effects of pre-ovulatory atresia on our estimate of potential fecundity, $\alpha$ stage atretic oocytes were not included in our estimation of egg number when applying the autodiametric method, as such oocytes do not contribute to final egg production. Under magnification, $\alpha$ atretic oocytes tended to be irregular in shape, relatively smaller than normal oocytes and with an uneven transparency (Óskarsson et al. 2002). Potential fecundity relationships differed in their calculation of relative condition $\left(K_{n}\right)$ from that previously noted in the respect that final gutted weight and expected gutted weight were used instead of wet weight and expected wet weight.

Statistical analyses. Our analysis was restricted to age1 individuals identified after analysis of their otoliths. Each sampling period was analysed using a logistic regression model (McCullagh \& Nelder 1983) that examined the influence of length, weight, G, I, rearing tank and sex on maturity. Maturity in these models was expressed as a 2-level factor (immature or mature), with tank and sex being expressed as factorial variables. Within the model the proportion to mature was expressed as a response function using a logit link function:

$$
\operatorname{logit}(p)=\log \left(\frac{p}{1-p}\right)
$$

where $p$ is the probability of maturing. An additional measure of model fit was based on a pseudo-coefficient of determination, $\mathrm{R}^{2}$, which was taken to be the fraction of the total variation explained by the model (Swartzman et al. 1995):

$$
\mathrm{R}^{2}=1-\left(\frac{\text { residual variance }}{\text { null variance }}\right)
$$

Fecundity versus size and condition relationships across the 2 tanks were then fitted within the framework of a general linear model (GLM) (Sokal \& Rohlf 1995). The model fitted to the data included all explanatory variables before non-significant effects were removed by a process of step-wise deletion. A plot of residuals against fits was plotted to confirm that the data tested complied with homogeneity of variance. Data were also tested for normality using an Anderson-Darling test.

\section{RESULTS}

Of the 182 individuals reaching the end of the present study in November, $60 \%$ belonged to the age- 1 cohort. Since, by November, mature individuals were in a late stage of vitellogenesis, maturity status could be assigned with a high degree of certainty. The proportion of age-1 individuals to mature differed between tanks, with $86 \%$ of individuals in Tank 1 maturing ( $86 \%$ female and $87 \%$ male) compared to $52 \%$ of individuals in Tank 2 (60\% male and $35 \%$ female).

\section{Gonadal development}

Cytological examination of samples taken throughout the study indicated that oocytes $<110 \mu \mathrm{m}$ were in the primary phase (perinucleolar stage), whilst those $>150 \mu \mathrm{m}$ were in the secondary phase (vitellogenic). All of the specimens collected in the initial June sample were immature with ovaries only containing primary oocytes. Endogenous vitellogenesis (cortical aveoli) stages were first detected during the second monitoring period in late July, whilst exogenous vitellogenesis (Fig. 1a) was detected in August. The maturity status of individuals could be defined in samples from August onwards in terms of whether the advanced oocytes were smaller or larger than $110 \mu \mathrm{m}$ in diameter. The recruitment of oocytes into exogenous vitellogenesis was associated with a rapid increase in oocyte diameter from a mean \pm SE of $149 \pm 35 \mu \mathrm{m}$ in August to $558 \pm 41 \mu \mathrm{m}$ by November.

As with females, all male specimens collected in the initial June samples were immature, exhibiting Type A spermatogonia. Males first exhibited Type B spermatogonia (Fig. 1b) in the lobules in late July. From October, spermatozoa became the dominant cells in lobules filling more than $50 \%$ of the lumen.

\section{Growth profiles before gonads}

Age-1 individuals in Tank 1, the first tank stocked, were significantly longer (11.1 vs. $10.2 \mathrm{~cm}, \mathrm{df}=106, t=$ 4.95, p < 0.001, 2-tailed $t$-test) and heavier (4.3 vs. $2.8 \mathrm{~g}$, $\mathrm{df}=106, t=6.92, \mathrm{p}<0.001$ ) than those in Tank 2 at the start of the present study. Taking all data together, GLM which included sex, tank and their interaction as explanatory variables did not reveal sex-related differences in either mean length (GLM: males $=10.6 \mathrm{~cm}$, females $=10.7 \mathrm{~cm}, F_{1,105}=0.07, \mathrm{p}=0.79$ ) or weight $\left(\right.$ GLM: males $=3.5 \mathrm{~g}$, females $=3.7 \mathrm{~g}, F_{1,105}=0.55$, $\mathrm{p}=0.46)$. Fig. $2 \mathrm{a}, \mathrm{b}$ shows mean weight and length grouped according to rearing tank and final maturity status at each sample period. When comparing the initial length $\left(\mathrm{L}_{0}\right)$ and weight $\left(\mathrm{W}_{0}\right)$ of individuals in Tank 1 grouped according to maturity status at the end of the present study, no significant difference in $\mathrm{W}_{0}$ (mature $=4.3 \mathrm{~g}$, immature $=3.8 \mathrm{~g}, \mathrm{df}=58, t=-1.40, \mathrm{p}=$ 0.17 ) or $\mathrm{L}_{0}$ (mature $=11.1 \mathrm{~cm}$, immature $=10.6 \mathrm{~cm}, \mathrm{df}=$ 
a

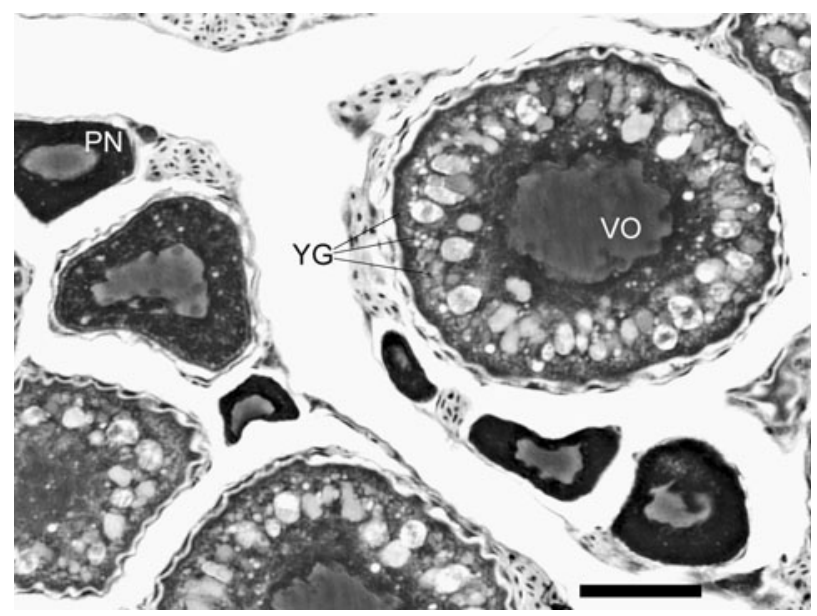

b

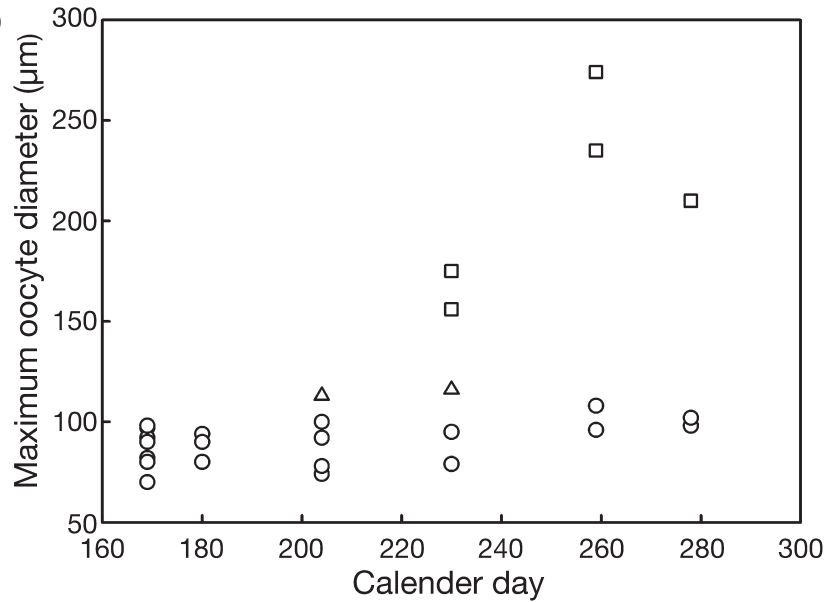

c

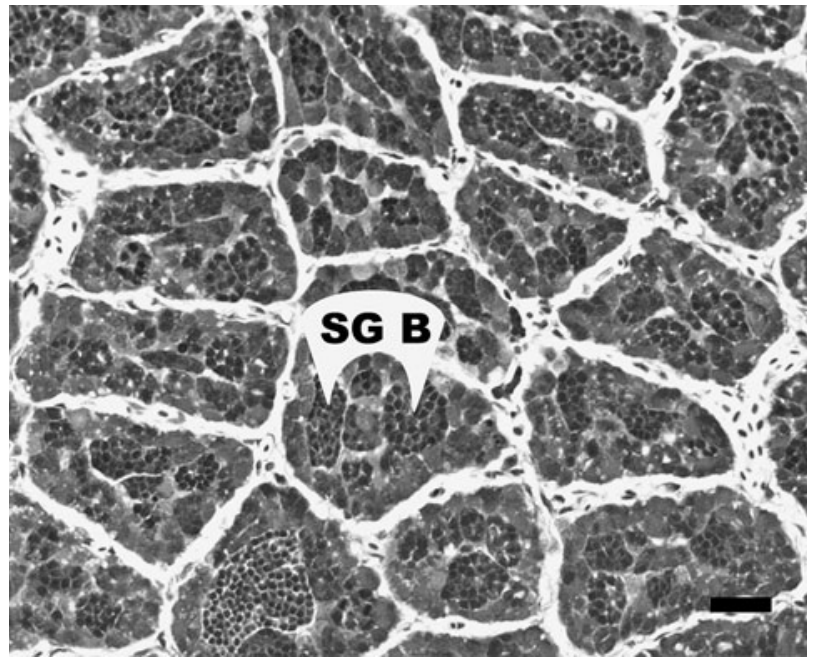

Fig. 1. Ammodytes marinus. Photomicrograph of (a) section through an ovary of a $13.1 \mathrm{~cm}$ mature female sampled $17 \mathrm{Au}-$ gust 2005 illustrating: primary oocytes (PN), yolk granules (YG) and exogenous vitellogenic oocytes (VO), scale bar = $50 \mu \mathrm{m}$. (b) Oocyte diameter against time during perinucleolar (O) and cortical aveoli stages $(\Delta)$ and for vitellogenic oocytes (ㅁ). (c) Testes of an $11.9 \mathrm{~cm}$ age-1 male sampled 22 July 2005 with lobules showing cysts with multiplying Type B spermatogonia (SG B), scale bar $=20 \mu \mathrm{m}$
$58, t=-1.46, \mathrm{p}=0.16$ ) could be found. A similar comparison in Tank 2 also did not reveal a significant difference in either $\mathrm{L}_{0}$ (mature $=10.2 \mathrm{~cm}$, immature $=10.1$ $\mathrm{cm}, \mathrm{df}=46, t=-0.72, \mathrm{p}=0.47$ ) or $\mathrm{W}_{0}$ (mature $=3.0 \mathrm{~g}$, immature $=2.6 \mathrm{~g}, \mathrm{df}=46 t=-1.97 \mathrm{p}=0.06$ ).

Except for non-maturing individuals reared in Tank 1, the period of the present study was characterised by an initial period of growth, both in length and weight, from July to mid/late September. A paired t-test ap-
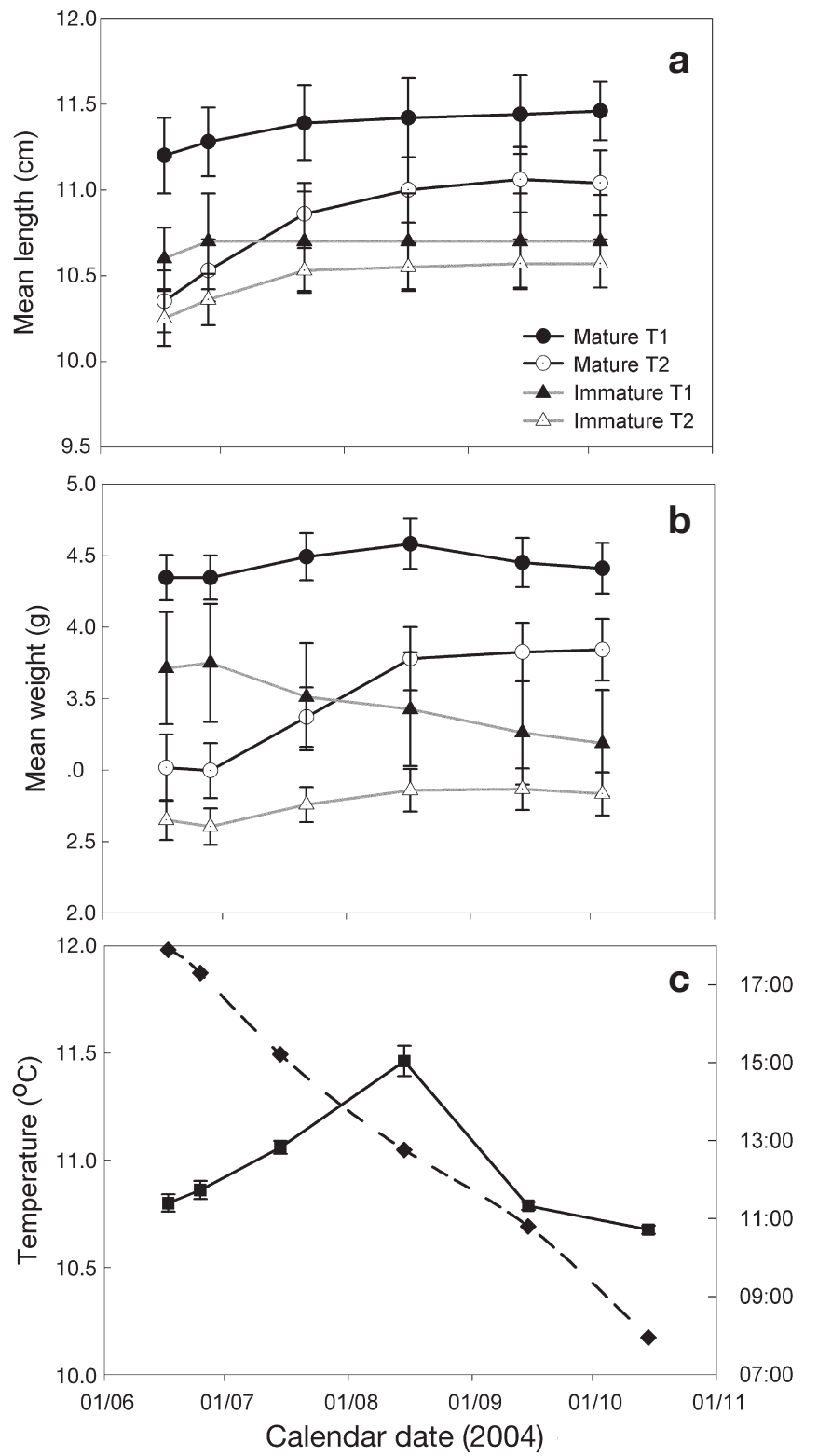

Fig. 2. Ammodytes marinus. Mean (a) length and (b) weight of sandeels recorded at each sampling bout grouped according to winter maturity status and rearing tank. Grey and black lines together with T1 and T2 identify individuals belonging to Tanks 1 and 2, respectively. Error bars denote standard error from the mean. (c) Tank temperature (- - ) and hours of daylight $(---$,$) recorded during the course of the study$ 
plied to maturing and non-maturing groups in each tank revealed that both maturing and non-maturing groups in Tank 1 underwent a period of weight loss from September to October (paired $t$-test: non-maturing, $t=5.66, \mathrm{p}<0.001$; maturing, $t=6.83, \mathrm{p}<0.001$ ), but maintained their weight in Tank 2 (paired $t$-test: non-maturing, $t=0.53, \mathrm{p}=0.60$; maturing, $t=-0.93$, $\mathrm{p}=0.36$ ). This period of weight loss coincided with the annual return of this species to the substrate and, hence, a marked drop in observed activity in the water column. The return to the substrate was also associated with a decline in temperature, with daily average temperature dropping over $1^{\circ} \mathrm{C}$ from its peak in midAugust (Fig. 2c). Increases in mean length were no longer evident at this time (September to November). Of all groups, maturing individuals in Tank 2 exhibited the highest rate of growth, enabling them to overtake non-maturing individuals in Tank 1 in size by August or September.

\section{Predictors of maturation probability}

The effect of length, weight, sex, rearing tank, G and I, measured during the first 4 sample bouts, were examined using a binary logistic regression to determine which variables, if any, were significant predictors of maturation. G and I were, in each instance, calculated on a forward-looking basis from each sample date. A binary logistic regression applied to data from both tanks revealed that only $\mathrm{W}_{0}$ and $\mathrm{L}_{0}$ in the first sampling period were significant predictors of final maturity state (Table 1). Applying the same model to the period suggested by cytological evidence to coincide with the time when fish commit to continued gonadal development (between 28 June and 22 July 2005) revealed $G$, weight and tank to be significant predictors of final maturity state, with maturing fish being larger and growing at a faster rate. A binary logistic regression applied to each tank individually during the same timeframe revealed $\mathrm{G}$ to be a significant predictor of maturation in Tank 1 and weight, length and sex to be significant explanatory variables in Tank 2. When analyzing data from both tanks collected from the time period succeeding the decision to commit to ongoing maturation, weight, length, tank and $\mathrm{G}$ were all revealed to be significant predictors of final maturity status.

\section{Fecundity}

$F_{\mathrm{PP}}$ of sandeels ranged from 1000 to 6000 oocytes. A regression analysis revealed a positive relationship between potential fecundity and length $\left(n=28, R^{2}=0.60\right.$,
Table 1. Results of the generalized linear models fitted to final maturation status according to tank. Length $\left(\mathrm{L}_{t}\right)$ and weight $\left(\mathrm{W}_{t}\right)$ recorded at the beginning of each sample period; specific growth rate $\left(\mathrm{G}_{(t-1)-t}\right)$, daily length increments $\left(\mathrm{I}_{(t-1)-t}\right)$, sex and rearing tank are expressed in these models as explanatory variables. $\mathrm{G}$ and I were calculated using data from the first 4 samples ( $t=0$ to 3 ) collected in the period between June and August

\begin{tabular}{|c|c|c|c|c|}
\hline & $z$ & $\mathrm{df}$ & $\mathrm{p}$ & $\mathrm{R}^{2}$ \\
\hline \multicolumn{5}{|c|}{ Both Tanks } \\
\hline \multicolumn{5}{|c|}{ Maximal model: Maturity $=$ Tank $+\mathrm{Sex}+\mathrm{G}_{0-1}+\mathrm{I}_{0-1}+\mathrm{W}_{0}+\mathrm{L}_{0}$} \\
\hline $\mathrm{W}_{0}$ & 3.34 & 1,107 & $<0.001$ & 0.10 \\
\hline $\mathrm{L}_{0}$ & -2.34 & 1,107 & 0.02 & 0.07 \\
\hline Sex & 1.70 & 1,107 & 0.09 & - \\
\hline $\mathrm{G}_{0-1}$ & 1.66 & 1,107 & 0.10 & - \\
\hline Tank & -0.88 & 1,107 & 0.38 & - \\
\hline$I_{0-1}$ & -1.38 & 1,107 & 0.98 & - \\
\hline \multicolumn{5}{|c|}{ Maximal model: Maturity $=$ Tank + Sex $+\mathrm{G}_{1-2}+\mathrm{I}_{1-2}+\mathrm{W}_{1}+\mathrm{L}_{1}$} \\
\hline $\mathrm{G}_{1-2}$ & 3.20 & 1,107 & $<0.01$ & 0.02 \\
\hline Tank & -2.75 & 1,107 & $<0.01$ & 0.20 \\
\hline $\mathrm{W}_{1}$ & 2.59 & 1,107 & $<0.01$ & 0.06 \\
\hline Sex & 1.44 & 1,107 & 0.15 & - \\
\hline $\mathrm{L}_{1}$ & -1.43 & 1,107 & 0.15 & - \\
\hline $\mathrm{I}_{1-2}$ & -0.72 & 1,107 & 0.47 & - \\
\hline \multicolumn{5}{|c|}{ Maximal model: Maturity $=$ Tank $+\mathrm{Sex}+\mathrm{G}_{2-3}+\mathrm{I}_{2-3}+\mathrm{W}_{2}+\mathrm{L}_{2}$} \\
\hline $\mathrm{W}_{2}$ & 3.72 & 1,107 & $<0.001$ & 0.14 \\
\hline $\mathrm{L}_{2}$ & -3.22 & 1,107 & $<0.01$ & 0.02 \\
\hline $\mathrm{G}_{2-3}$ & 3.21 & 1,107 & $<0.01$ & 0.03 \\
\hline Tank & -2.57 & 1,107 & 0.01 & 0.22 \\
\hline Sex & 1.30 & 1,107 & 0.19 & - \\
\hline $\mathrm{I}_{2-3}$ & -0.30 & 1,107 & 0.76 & - \\
\hline \multicolumn{5}{|c|}{ Tank 1 only } \\
\hline \multicolumn{5}{|c|}{ Maximal model: Maturity $=\mathrm{Sex}+\mathrm{G}_{1-2}+\mathrm{I}_{1-2}+\mathrm{W}_{1}+\mathrm{L}_{1}$} \\
\hline $\mathrm{G}_{1-2}$ & 2.75 & 1,59 & $<0.01$ & 0.29 \\
\hline $\mathrm{W}_{1}$ & 1.76 & 1,59 & 0.08 & - \\
\hline $\mathrm{L}_{1}$ & -0.25 & 1,59 & 0.80 & - \\
\hline$I_{1-2}$ & -0.22 & 1,59 & 0.82 & - \\
\hline Sex & -0.03 & 1,59 & 0.97 & - \\
\hline \multicolumn{5}{|c|}{ Tank 2 only } \\
\hline \multicolumn{5}{|c|}{ Maximal model: Maturity $=\mathrm{Sex}+\mathrm{G}_{1-2}+\mathrm{I}_{1-2}+\mathrm{W}_{1}+\mathrm{L}_{1}$} \\
\hline $\mathrm{W}_{1}$ & 2.52 & 1,47 & 0.01 & 0.15 \\
\hline $\mathrm{L}_{1}$ & -2.30 & 1,47 & 0.02 & 0.01 \\
\hline Sex & 2.41 & 1,47 & 0.02 & 0.05 \\
\hline $\mathrm{G}_{1-2}$ & 1.67 & 1,47 & 0.09 & - \\
\hline$I_{1-2}$ & -0.83 & 1,47 & 0.40 & - \\
\hline
\end{tabular}

$F=39.57, \mathrm{p}<0.001$ ), best expressed as a power equation: $F_{\mathrm{PP}}=0.0082 \times \mathrm{L}^{5.2811}$. However, when weight, tank and oocyte diameter were included with length as explanatory variables, length (GLM: $\mathrm{df}=1, F=0.25, \mathrm{p}=$ $0.62)$, rearing tank ( $\mathrm{df}=1, F=0.39, \mathrm{p}=0.56$ ) and oocyte diameter ( $\mathrm{df}=1, F=2.56, \mathrm{p}=0.12$ ) could be removed from the model, leaving gutted weight $\left(\mathrm{W}_{\text {gut }}\right)(\mathrm{df}=1, F=$ $66.1, \mathrm{p}<0.001, \mathrm{R}^{2}=0.72$ ) as the sole significant variable (Fig. 3). A GLM applied to relative fecundity data revealed a significant effect of length $(\mathrm{df}=1, F=5.88, \mathrm{p}=$ $\left.0.02, \mathrm{R}^{2}=0.18\right)$ but not tank ( $\mathrm{df}=1, F=0.99, \mathrm{p}=0.33$ ), gutted weight $(\mathrm{df}=1, F=0.14, \mathrm{p}=0.71$ ) or mean oocyte diameter $(\mathrm{df}=1, F=2.61, \mathrm{p}=0.12)$. 


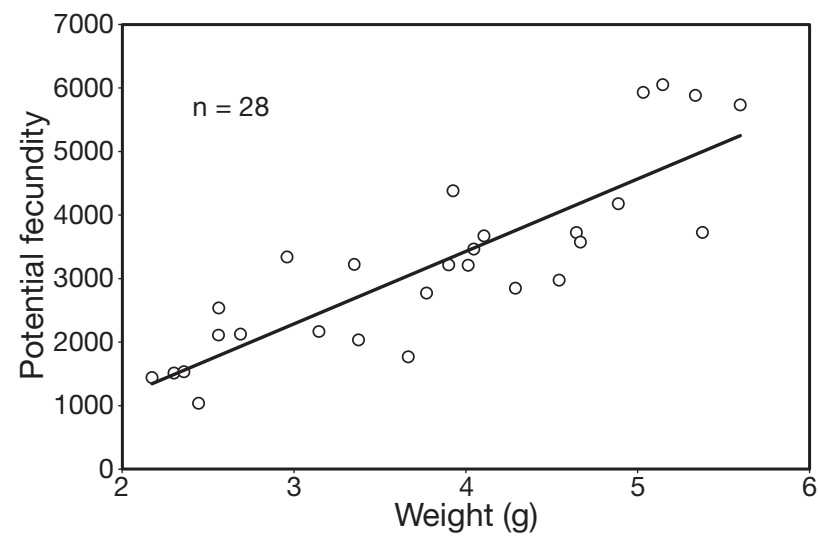

Fig. 3. Ammodytes marinus. Relationship between predicted potential fecundity $\left(F_{\mathrm{PP}}\right)$ and gutted weight $\left(\mathrm{W}_{\text {gut }}\right): F_{\mathrm{PP}}=$ $1140.6 \mathrm{~W}_{\text {gut }}-1133.6 ; \mathrm{n}=28, \mathrm{R}^{2}=0.72$

\section{DISCUSSION}

\section{Critical period}

Cytological investigation indicates that the decision of whether or not to maintain investment in reproduction in Ammodytes marinus occurs during the summer prior to the winter spawning period. In females, the presence of a hiatus in oocyte diameter separating primary and vitellogenic oocytes suggests that oocytes were recruited at the transition between the primary and secondary phase, a stage at which other deterministic-group, synchronous spawners commit to spawning (Kjesbu 1994). Thus, the key indicator of allocation to reproduction is the developmental transition from primary to secondary oocytes. The transition to exogenous vitellogenesis occurred in late July/August, just prior to the time when sandeels begin over-wintering in the sand and cease investing in somatic growth. Characterized by the increase in vitellogenic oocyte size, the largest period of energetic allocation to the gonads occurs between August and November, during their period of over-wintering. These observations substantiate field-based analyses of gonad size that indicate that the major change in gonadosaomatic index occurs from September to December (Bergstad et al. 2001). Maturing males underwent spermatogenesis in late July and August, suggesting that the divergence of development patterns takes place around the same time of year as that of females.

Given the early phase of gonad development in June it appears likely that sandeels make the decision to commit to reproduction well in advance of the lifehistory event. Hence, sandeels would have to decide whether to allocate significant resources to reproduction on the basis of some proximate factor prior to August. Our results also indicate that the proximate factors likely to be responsible for the continuation of maturation past this period include the rate of energy intake and body weight, with larger and faster growing individuals reaching maturity. The presence of a critical period in which maturation is determined has been found in other species of fish, including the Atlantic salmon Salmo salar (Rowe \& Thorpe 1990, Rowe et al. 1991) and winter flounder Pleuronectes americanus (Roff 1983, Burton 1994). Clearly, further studies would be desirable to confirm the proposed critical period. Similar studies for other species have involved either the manipulation of photoperiod (Adams \& Thorpe 1989) or food ration (Burton 1994) during certain periods of the growing season.

\section{Proximal influences on maturation}

In terms of life history, it is likely that the mechanisms individuals use to characterise their optimum developmental strategy are based on a comparison of their physiological state (and its rate of change) within a genetic threshold (Thorpe et al. 1998). Whilst the precise developmental mechanism underpinning maturation is unknown, the results from our regression analysis support such a concept of physiological assessment, with length, weight and $\mathrm{G}$ as explanatory variables. Mean growth rates within both tanks were comparable to those derived from historic data of age-1 fish collected from the Firth of Forth (Wanless et al. 2004, P. J. Wright unpubl. data) and, hence, the results obtained from the present study are likely to mirror those from wild populations.

Our model also revealed a significant effect of tank on maturation during later sample periods, and it is clear from mean weight/length distributions in each of the 2 tanks that individuals from Tank 1 started from a more advanced position with respect to size. Individuals in Tank 1 had been transferred from the wild almost a month earlier and were larger, heavier and in better condition at the outset of the present study, producing a higher proportion of mature individuals come November. That weight, length and sex were found to be explanatory variables in Tank 2 rather than $G$, when analyzing data collected in late June and July, could possibly relate to the fact that individuals belonging to this tank were smaller at the onset of the experiment. Here the constraint of initial size on maturation was evident with only the fastest growing individuals from the lower range of initial sizes having any chance of maturing.

Switch-based threshold levels of energy storage have been documented in other species of fish (Tyler \& Dunn 1976, Thorpe 1986, Henderson \& Nepszy 1994), and it is possible that such physiological levels represent a developmental threshold for maturation in this 
population. Here, the physiological state for the fish is prescribed by environmental opportunity with the threshold levels interacting with the environment via growth (Thorpe et al. 1998). Such threshold levels are likely to be genetic (Aubin-Horth et al. 2005), with the life-history outcome determined by the setting of such ultimate regulators via the influence of natural selection.

\section{Cost of reproduction}

Early maturity enhances fitness by reducing the time in which juvenile predation may occur and by producing offspring that are able, in turn, to start reproducing earlier (Cole 1954). However, if energy resources of the individual are too low, then allocation to reproduction without sufficient energy stores could result in an increase of over-winter and pre-spawning mortality in Ammodytes marinus. Given the energetic tradeoff between growth and reproduction, individuals that delay maturity might be expected to have lower energy reserves just prior to the timing of the investment decision and to have faster growth, relative to maturing individuals, following this decision (Poizat et al. 1999). No such tradeoff between growth and reproduction was found in the present study. Rather, individuals that did not mature displayed lower growth than their mature counterparts.

The absence of an inverse relationship between these life-history traits is likely to be due to the fact that individual variation in the magnitude of stored resources or resource accrual abilities masks the true energetic cost of maturation (van Noordwijk \& de Jong 1986, Sinervo \& DeNardo 1996). Since gonadal steroids enhance growth, it is also likely that during an active gonadal growth phase such individuals grow faster than those not so steroid-stimulated. The present study did not examine over-winter mortality, and it is probable that this exclusion leads to the underestimation of the true cost of reproduction. Masking of reproductive costs has been seen in other taxonomic groups of organisms (e.g. molluscs: McGrath \& Jackson 2002; amphibians: Lardner \& Loman 2003; reptiles: Schwarzkopf 1993).
Length-fecundity relationships produced for wildcaught sandeels tend to be lower than the relationship found in the present study, i.e. for a $12 \mathrm{~cm}$ sandeel, fecundity has been reported to vary from 2706 to 3531 eggs (Gauld \& Hutcheon 1990) and up to 4053 eggs (Macer 1966), compared to our estimate of 4103 eggs. The fact that our relationship was higher, although still within the range recorded previously for this species (Macer 1966, Wanless et al. 2004), could reflect the favourable nature of the nutritive conditions in which fish were reared.

The results of the present study highlight that both growth rate and size within a short developmental window affect the decision to mature in the sandeel. Changes in the timing of the availability of their zooplankton prey could therefore have a substantial effect on the proportion of sandeels maturing at different ages, resulting in large changes in the size of the spawning stock. Given the profound changes in the biomass and phenology of plankton in the North Sea in the past few decades (Edwards et al. 2002, Reid et al. 2003) and the significant changes in size of sandeels in some parts of their range (Wanless et al. 2004), significant temporal variability in maturation rates may be expected. Current stock assessments do not, however, consider the potential for inter-annual variability in maturation rate (ICES CM 2006) despite field studies finding significant regional differences in age at maturity (Gauld \& Hutcheon 1990, Bergstad et al. 2001, Boulcott et al. 2006). Further work is needed to explore the relationship between regional growth opportunity and maturation timing. Moreover, given the apparent changes in prey phenology, future studies should consider the consequence of this variability to the reproductive potential and sustainability of sandeel aggregations.

Acknowledgements. This work was supported by the Danish Institute for Fisheries Research, the Scottish Executive and the University of Aberdeen. We are grateful to I. Gibb for otolith reading, to B. Williamson, R. Long and P. Gibson for technical assistance and skilful husbandry of the study fish and to F. Neat for assistance during sampling and for constructive criticism of the manuscript. All work was carried out under a UK Home Office Animals (Scientific Procedures) license.

\section{Fecundity}

As predicted by life-history theory, we found the fecundity of sandeels reared in the present study to be strongly influenced by weight. That length was not a significant predictor of potential fecundity when weight was included reflects the fact that these explanatory variables are correlated with each other.

\section{LITERATURE CITED}

Adams CE, Thorpe JE (1989) Photoperiod and temperature effects on early development and reproductive investment in Atlantic salmon (Salmo salar L.). Aquaculture 79: 403-410

Aubin-Horth N, Landry CR, Letcher BH, Hofmann HA (2005) Alternative life histories shape brain gene expression profiles in males of the same population. Proc R Soc Ser B 272: $1655-1662$ 
Bagenal T (1978) Methods for the assessment of fish production freshwaters, 3rd edn. Blackwell Scientific, Oxford

> Bergstad OA, Høines ÅS, Krüger-Johnsen EM (2001) Spawning time, age and size at maturity, and fecundity of sandeel, Ammodytes marinus, in the north-eastern North Sea and in un-fished coastal waters off Norway. Aquat Living Resour 14:293-301

Boulcott P, Wright PJ, Gibb FM, Jensen H, Gibb IM (2006) Regional variation in maturation of sandeels in the North Sea. ICES J Mar Sci 64:369-376

Burton MPM (1994) A critical period for nutritional control of early gametogenesis in female winter flounder, Pleuronectes americanus (Pisces: Teleostei). J Zool (Lond) 233: 405-415

> Campbell B, Dickey J, Beckman B, Young G, Pierce A, Swanson $P$ (2003) Endocrine changes associated with the growth of pre-vitellogenic oocytes in coho salmon, Oncorhynchus kisutch. Fish Physiol Biochem 28:287-289

Campbell B, Dickey J, Beckman B, Young G, Pierce A, Fukada H, Swanson P (2006) Previtellogenic oocyte growth in salmon: relationships among body growth, plasma insulin-like growth factor-1, estradiol-17beta, folliclestimulating hormone and expression of ovarian genes for insulin-like growth factors, steroidogenic-acute regulatory protein and receptors for gonadotropins, growth hormone, and somatolactin. Biol Reprod 75:34-44

> Cole LC (1954) The population consequences of life-history phenomena. Q Rev Biol 29:103-137

> Dziewulska K, Domagala J (2003) Histology of salmonid testes during maturation. Reprod Biol 3:47-61

Edwards M, Beaugrand G, Reid PC, Rowden AA, Jones MB (2002) Ocean climate anomalies and the ecology of the North Sea. Mar Ecol Prog Ser 239:1-10

Fisher RA (1930) The genetical theory of natural selection. Oxford University Press, Oxford

Gauld JA, Hutcheon JR (1990) Spawning and fecundity in the lesser sandeel (Ammodytes marinus, Raitt) tagged in the north-western North Sea. J Fish Biol 36:611-613

> Gjedrem T, Haus E, Halseth V (1986) Genetic variation in reproductive traits in Atlantic salmon and rainbow-trout. Aquaculture 57:369

Henderson BA, Nepszy SJ (1994) Reproductive tactics of walleye (Stizostedion vitreum) in Lake Erie. Can J Fish Aquat Sci 51:986-997

> Henderson BA, Wong JL (1998) Control of lake trout reproduction: role of lipids. J Fish Biol 52:1078-1082

ICES CM (1995) Report of the ICES workshop on sandeel otolith analysis. ICES CM 1995/G:4 1-31

ICES CM (2006) Working group on the assessment of demersal stocks in the North Sea and Skagerrak. ICES Document CM 2006/ACFM:09

Kjesbu OS (1994) Timing of start of spawning in Atlantic cod (Gadus morhua) females in relation to vitellogenesis oocyte diameter, temperature, fish length and condition. J Fish Biol 45:719-735

Kjesbu OS, Witthames PR, Solemdal P, Walker MG (1998) Temporal variations in the fecundity of Arcto-Norwegian cod (Gadus morhua) in response to natural changes in food and temperature. J Sea Res 40:303-321

Lardner B, Loman J (2003) Growth or reproduction? Resource allocation by female frog Rana temporaria. Oecologia 137: 541-546

Le Cren ED (1951) The length-weight relationship and seasonal cycle in gonad weight and condition in the perch (Perca flaviatilis). J Anim Ecol 20:201-219

Macer CT (1966) Sand eels (Ammodytidae) in the southwestern North Sea; their biology and fishery. Fish Invest
Lond II 24:1-55

McCullagh P, Nelder JA (1983) Generalized linear models. Chapman \& Hall, London

> McGrath GL, Jackson GD (2002) Egg production in the arrow squid Nototodarus gouldi (Cephalopoda: Ommastrephidae), fast and furious or slow and steady? Mar Biol 141:699-706

> Norberg B, Weltzien FA, Karlsen O, Holm JC (2001) Effects of photoperiod on sexual maturation and somatic growth in male Atlantic halibut (Hippoglossus hippoglossus L.). Comp Biochem Physiol B 129:357-365

Óskarsson GJ, Kjesbu OS, Slotte A (2002) Predictions of realised fecundity and spawning time in Norwegian spring-spawning herring (Clupea harengus). J Sea Res 48:59-79

Poizat G, Rosecchi E, Crivelli AJ (1999) Empirical evidence of a trade-off between reproductive effort and expectation of future reproduction in female three-spined sticklebacks. Proc Roy Soc B Biol Sci 266: 1543

Raitt DS (1934) A preliminary account of the sandeels of Scottish waters. J Conseil 9:365-372

Reid PC, Edwards M, Beaugrand G, Skogen M, Stevens D (2003) Periodic changes in the zooplankton of the North Sea during the twentieth century linked to oceanic inflow. Fish Oceanogr 12:260-269

Rijnsdorp AD (1993) The relation between juvenile growth and the onset of sexual maturity of female North Sea plaice, Pleuronectes platessa L. Can J Fish Aquat Sci 50: 1617-1631

Roff DA (1983) An allocation model of growth and reproduction in fish. Can J Fish Aquat Sci 39:1686-1698

Roff DA (1991) The evolution of life-history variation in fishes, with particular reference to flatfishes. Neth J Sea Res 27: 197-207

Roff DA (1992) The evolution of life histories. Chapman \& Hall, New York

Roff DA (2002) Life-history evolution. Sinauer Associates, Sunderland, MA

$>$ Rowe DK, Thorpe JE (1990) Differences in growth between maturing and non-maturing male Atlantic salmon, salmosalar L., parr. J Fish Biol 36:643-658

> Rowe DK, Thorpe JE, Shanks AM (1991) Role of fat stores in the maturation of male Atlantic salmon (salmo-salar) parr. Can J Fish Aquat Sci 48:405-413

Schwarzkopf L (1993) Costs of reproduction in water skinks. Ecology 74:1970-1981

Scott AP, Sumpter JP (1983) A comparison of the female reproductive cycle of autumn-spawning and winterspawning strains of rainbow trout (Salmo gairdneri Richardson). Gen Comp Endocrinol 52:79-85

Sinervo B, DeNardo DF (1996) Costs of reproduction in the wild: path analysis of natural selection and experimental tests of causation. Evolution 50:1299-1313

Sokal RR, Rohlf FJ (1995) Biometry. Freeman, New York

Stearns SC (1992) The evolution of life histories. Oxford University Press. Oxford

Svåsand T, Jørstad KE, Otterå H, Kjesbu OS (1996) Differences in growth performance between Arcto-Norwegian and Norwegian coastal cod reared under identical conditions. J Fish Biol 49:108-119

Swartzman G, Silverman E, Williamson N (1995) Relating trends in walleye pollock (Theragra chalcogramma) abundance in the Bering Sea to environmental factors. Can J Fish Aquat Sci 52:369-380

Thorpe JE (1986) Environmental regulation of growth patterns in juvenile salmon. In: Summerfelt RC, Hall GE (eds) Age and growth of fish. Iowa State University Press, Ames, p 463-474 
Thorpe JE, Morgan RIG, Talbot C, Miles MS (1983) Inheritance of developmental rates in Atlantic salmon, salmosalar L. Aquaculture 33:119-128

Thorpe JE, Talbot C, Miles MS, Keay DS (1990) Control of maturation in cultured Atlantic salmon, salmo-salar, in pumped seawater tanks, by restricting food-intake. Aquaculture 90:41-47

Thorpe JE, Mangel M, Metcalfe NB, Huntingford FA (1998) Modelling the proximate basis of salmonid life-history variation, with application to Atlantic salmon, Salmo salar L. Evol Ecol 12:581-599

Thorsen A, Kjesbu OS (2001) A rapid method for estimation of oocyte size and potential fecundity in Atlantic cod using a computer-aided particle analysis system. J Sea Res 46: 295-308

Tyler AV, Dunn RS (1976) Ration, growth, and measures of somatic and organ condition in relation to meal frequency in winter flounder, Pseudopleuronectes americanus, with hypothesis regarding population homeostasis. J Fish Res Board Can 11:933-953

Tyler CR, Sumpter JP (1996) Oocyte growth and development

Editorial responsibility: Matthias Seaman,

Oldendorf/Luhe, Germany in teleosts. Rev Fish Biol Fish 6:287-318

van Noordwijk AJ, de Jong G (1986) Acquisition and allocation of resources: their influence on variation in life-history tactics. Am Nat 128:137-142

Wanless S, Wright PJ, Harris MP, Elston DA (2004) Evidence for decrease in size of lesser sandeels Ammodytes marinus in a North Sea aggregation over a 30-yr period. Mar Ecol Prog Ser 279:237-246

Winslade P (1971) Behavioural and embryological investigations of the lesser sandeel, Ammodytes marinus, Raitt. $\mathrm{PhD}$ thesis, The University of East Anglia, Norwich

Winslade P (1974a) Behavioural studies on the lesser sandeel Ammodytes marinus (Raitt) II. The effect of light intensity on activity. J Fish Biol 6:577-586

Winslade P (1974b) Behavioural studies on the lesser sandeel Ammodytes marinus (Raitt) III. The effect of temperature on activity and the environmental control of the annual cycle of activity. J Fish Biol 6:577-586

Wright PJ, Jensen H, Tuck ID (2000) The influence of sediment type on the distribution of the lesser sandeel, Ammodytes marinus. J Sea Res 44:243-256

Submitted: June 22, 2007; Accepted: May 20, 2008

Proofs received from author(s): June 24, 2008 